Millatī, Journal of Islamic Studies and Humanities

Vol. 4, No. 1, Juni 2019: h. 14-34. DOI: 10.18326/mlt.v4i1.14-34

p-ISSN : 2541-3627; e-ISSN 2540-9964

Website: http://millati.iainsalatiga.ac.id/index.php/millati/index

\title{
Hadith Book of Middle Age : The Study of Al-Targīb Wa Al-Tarhīb Book by Al- Munżirī
}

\author{
Muhammad Anshori \\ Pascasarjana UIN Sunan Kalijaga Yogyakarta \\ anshori92@gmail.com/081917234275
}

\begin{abstract}
This paper attempts to describe and analyze one of the anthologies or secondary hadith books of medieval, namely al-Targïb wa al-Tarbib by al-Munżirī (581-656 H). This book has quite a lot of hadith, so it is natural that the quality is varied, sabih, hasan, and daif (with various forms). Al-Targib wa al-Tarhib can be categorized as a book of adab or morality of a Muslim that can be a provision of life in the world and the hereafter. The Hadiths contained in the book contain quite complex themes or topics, ranging from life in the world and the hereafter. But what is certain is that the book al-Targib wa al-Tarbib was written not at the initiative of al-Munzirī himself, but was a request from one of his students. After praying or asking God for guidance, some time later he was willing to write the book. Al-Munżirī did not just include the quoted hadiths, but also gives an assessment and explains the words that are considered difficult to be understood. Thus, he has also conducted research on hadith.
\end{abstract}

Keywords: Book of Hadith, Middle Ages/Medieval, al-Targīb wa al-Tarbīb, al-Munżirī.

\begin{abstract}
Abstrak
Tulisan ini berusaha mendeskripsikan dan menganalisis salah satu kitab hadis sekunder atau antologi abad tengah, yaitu al-Targīb wa al-Tarbīb karya al-Munżirī (581-656 H). Kitab ini memiliki hadis yang cukup banyak, sehingga wajar jika kualitasnya beragam, sabih, hasan, dan daif (dengan beragam bentuknya). Kitab al-Targib wa al-Tarbib bisa dikategorikan sebagai kitab adab atau akhlak seorang Muslim yang bisa menjadi bekal kehidupan dunia dan akhirat. Hadis-hadis yang dimuat dalam kitab tersebut mengandung tema atau topik yang cukup kompleks, mulai dari kehidupan di dunia dan akhirat. Namun yang pasti bahwa kitab al-Targīb wa al-Tarbïb ditulis bukan atas inisiatif al-Munżirī sendiri, tetapi merupakan permintaan dari salah seorang muridnya. Setelah berdoa atau minta petunjuk kepada Allah, beberapa waktu kemudian beliau bersedia menulis kitab tersebut. Al-Munżirī tidak hanya mencantumkan begitu saja hadis-hadis yang dikutip, tetapi juga memberikan penilaian dan menjelaskan kata-kata yang dianggap sulit dipahami. Dengan demikian, beliau juga telah melakukan pensyarahan terhadap hadis.
\end{abstract}

Kata Kunci: Kitab Hadis, Abad Tengah, al-Targīb wa al-Tarbīb, al-Munżirī. 


\section{INTRODUCTION}

The study of hadith will never stop until the end of this world. Since the time of Prophet Muhammad, his "sunnah" which was later noted by his fellows, has been able to change the outlook of human life. Hadith is a transformation from the "sunnah" which experiences a long historical process. This is a problem faced by orientalists. Regardless of the polemic, the majority of Muslims recognize hadith as the second source of Islamic teaching after the Quran (primary souces). For some circles, the source of Islamic teaching is only one, namely the Quran, as said by Taufĩq al-Șidqī (1881-1920) in his article entitled "al-Islām Huwa al-Qur'ān Waḥdah" (al-Manar, IX , p. 515-524). This paper had caused polemics in Egypt at that time ${ }^{1}$. The author himself agreed with the statement, because indeed one of the functions of hadith is to explain the contents of the Quran.

The process of codifying the hadith took long time, about 2 (two) centuries. Then the main process occurred in the third century $(3 \mathrm{AH})$ with the emergence of hadith scholars, according to Abu Syahbah this period was called the golden age of hadith codification (al-șașr al-abababi li tadwin al-hadisis). The next process, in the 6th and 7th centuries $\mathrm{AH}$, there were the scholars of hadith who studied the previous books. They wrote secondary books of hadith as guidance books on their time. One of the secondary books in the 6-7th century AH. was al-Targīb wa al-Tarhīb by al-Munziirī (581-656 AH). This book was categorized as a book of hadith written in midieval age. This book is the focus of discussion in this study. Before analyzing the book, it will first explain the brief history of the books of hadith until the middle age.

\section{Style of Writing Hadith Book at Middle Age}

According to Harun Nasution, generally the history of Islamic civilization could be divided into three periods ${ }^{2}$ First, the classical period, namely the age of development, which is divided into two phases: (1). The phase of expansion, integration, and development (6501000 AD), the phase of Islam extended to North Africa, Spain in the West, and Persia, India to the East that was subject to the Caliphate resided in Medina, then in Damascus, and the last in Baghdad. During this time, fiqh scholars such as Abū Hanīfah (w. 150 AH), Mālik (w. 179 AH), al-Syāfi'ī (w. 204 AH), and Aḥmad (w. 241 AH). Wāṣil bin 'Ațā’' (w. 131 AH), al-Asy'arī (d. 324 AH / 935 AD), al-Mātūridī (d. 333 AH / 944 AD), in science of kalam. Żunnun al-Mișrī (w. 246 AH / 856 AD), Abū Yazīd al-Busțāmī (w. 261 AH / 875 AD), and al-Ḥallāj (w. 922 AD) in mysticism or Sufism. Al-Kindī (w. 866 AD), al-Fārabī (257-339 AH / 870-950 AD), Ibn Sinā, Ibn Miskawaih (d. 421 AH / 1030 AD) in philosophy. Ibn Hais̉am, Ibn Ḥayyān, al-Khawārizmī, al-Mas'ūdī, al-Rāzīe in science. (2). The integration phase (1000-1250), Islam began to break out in politics because the

${ }^{1}$ See Juynboll, G.H.A., The Authenticity of the Tradition Literature Discussions (Leiden: E.J. Brill, 1969), Indonesian edition translated by Ilyas Hasan, Kontroversi Hadis di Mesir (1890-1960) (Bandung: Penerbit Mizan, cet-I, 1420 H/1999 M), p. 32-46. See Amal, Taufik Adnan., Islam dan Tantangan Modernitas: Studi atas Pemikiran Hukum Fą̧ur Rabman (Bandung: Penerbit Mizan, cet-V, 1414 H/1994 M), p. 86-87.

2 See Nasution, Harun., Pembaharuan dalam Islam: Sejarah, Pemikiran dan Gerakan (Jakarta: PT Bulan Bintang, 1982), p. 13-14. Nasution, Harun., Islam ditinjau Dari Berbagai Aspeknya (Jakarta: UI-Press, cet-V, 1985), Islam Rasional: Gagasan dan Pemikiran (Bandung: Penerbit Mizan, cet-IV, 1416 H/1996 M), p. 181-183. 
caliphate's power began to decline which was marked with seizeing and destroying Baghdad by Hulagu Khan in 1258. In this phase, the caliphate was known as a symbol of fallen political unity.

Second, Medieval Period (1250-1800), it was divided into three phases. (1). Backdown phase (1250-1500), or referred to as a period of increasing disintegration. This was designated by the difference between Sunni and Syi'ah or between Arabs and Persians. The Islamic world is famous for two different sides, namely Arabic, which consists of Arabia, Iraq, Syria, and Palestine, Egypt as the center. While in another part was Persia, which consisted of Bulkan, Little Asia, Persia, Central Asia and Persia as the center. (2). Phase of three great kingdoms (1500-1800), which was called as the age of development (15001700). (3). Backdown age (1700-1800). The three kingdoms referred to Usmani kingdom in Turkey, Safawi kingdom in Persia (Iran), and Mongol kingdom in India. The achievement obtained in this phase was the beautiful Islamic architecture in the form of buildings and mosques. Third, the modern age (1800 - now), it was the rise of Muslims. Egypt fell to the West made Muslims aware of their weaknesses, and the Western civilization was highly increased. During this period, the ideas of Islamic reform began to emerge.

As it was known that the writing of hadith had begun since the period of Prophet Muhammad. It was admitted that at that time he had forbidden to write his words, but there were several traditions which allowed this. Since there was an order from the 8th Caliphate of Bani Umayyah dynasty, namely 'Umar bin' Abdul 'Azīz (w. 101 AH / 720 AD), ${ }^{3}$ the collection, writing and bookkeeping of hadith began to develop in Muslim territories. This instruction was first addressed to the Governor of Medina, Abū Bakr ibn Muhammad bin 'Amru bin Hazm (w. 117 AH / 735 AD).

'Umar bin' Abdul 'Azīz also ordered Abu Bakar bin Hazm to write hadiths in the hands of 'Amrah binti 'Abdur Raḥmān al-Anșārīyah and Qāsim bin Muḥammad bin Abū Bakar. In addition, the Caliphate also wrote letters to officials in Islamic jurisdictions to write hadiths. The person who first collected and wrote the hadith by orders of 'Umar bin' Abdul 'Azīz was Muḥammad bin Syihāb al-Zuhrī (w. 124 AH). Then it was followed by Ibn Juraij (w. 150 AH) in Makkah, Ibn Isḥāq (w. 151 AH), Mālik bin Anas (w. 179 AH) in Medina, Rabī 'bin Șabịh (w. 160 AH), Sa'īd bin Abū 'Arūbah (w. 156 AH) and Ḥammād bin Salamah (w. 176 AH) in Baṣrah, Sufyān al-īaurī (w. 161 AH) in Kufa, al-Auzā'ì (w. 156

3 al-Suyūṭī, Jalāluddīn Abū al-Faḍl Abdur Raḥmān bin Abu Bakar., Tadrīb al-Rāwì fì Syarḥi Taqrīb alNawāwì, ditaḥqīq oleh 'Abdur Raḥmān al-Muḥammadī (Beirut: Dār al-Kutub al-'Ilmiyyah, cet-I, 2009 M), p. 63. Jika diperhatikan dengan seksama, secara umum ada dua alasan mengapa 'Umar bin 'Abdul 'Azīz memerintahkan pengkodifikasian hadis; Pertama, para ulama hadis telah tersebar ke berbagai negeri (seperti Makkah, Madinah, Damaskus, Bagdad, Mesir, dan sebagainya) dikhawatirkan hadis akan hilang bersamaan dengan wafatnya mereka, sedangkan generasi penerus diperkirakan tidak akan menaruh perhatian pada hadis. Kedua, banyak berita dan ungkapan yang dibuat-buat atau dipalsukan oleh pelaku bid'ah, seperti Khawārij, Syi'ah, Mu'tazilah, Qadariyah, Jabariyah, dan lain-lain. Kemudian ungkapan-ungkapan itu dinisbatkan kepada Nabi. Menurut beberapa data sejarah, Syi'ah merupakan kelompok yang pertama kali dan banyak membuat hadis palsu atau maudu. 
AH ) in Syam, Husyaim (w. 188 AH) in Wāsiț, Ma'mar (w. 153 AH) in Yaman, Jarīr bin 'Abdul Humaid (w. 188 AH) and Ibn al-Mubārak (w. 181 AH) in Khurasan ${ }^{4}$

As it was known that the scholars of hadith above were living during that time, so it was unknown who among those who first collected hadith. Of all the works of scholars above, none of them got to us. The famous book that we found now is al-Muwatta' 'by Mālik bin Anas (w. 179 AH), al-Musnad by al-Syāfi'ì (w. 204 AH / 820 AD) and al-Āंs̄är by Muhammad bin Hasan al-Syaibān̄̄.

Many scholars wrote book of hadiths with various models, forms or patterns such as al-Masānìd, al-Sunan, al-Șaḥih, al-Ma'äjim, al-Arba'in, al-Mustadrakat, al-Mustakhrajät, alMuṭa'a'at, al-Mușannafät, and many more. Among them were Mālik (w.179 AH), al-Bukhārī (w. 256 AH), Muslim (w. 875 M / 261 AH), Abū Dāwud (w. 889 AD / 275 AH), al-Nasā'ī (w. 915 AD / 303 AH), al-Tirmizì (w. 892 AD / 279 AH), Ahmad (w. 855 AD / 241 AH), Ibn Hibbān (w. 354 AH), Ibn Khuzaimah (w. 311 AH) ), al-Ḥākim (w. 405 AH), and so on. Books of hadith that were circulated and studied were al-Kutub al-Sittah or al-kutub al-tis'ah. Finally, there were three more books added (al-Munvatța 'by Mālik (w. $179 \mathrm{H}$ ), al-Musnad by Aḥmad (w. 241 AH / 855 AD), and al-Sunan by al-Dārimī (w. 255 AH / 869 AD), so it was known as al-kutub al-tis'ah.

Generally, books of hadith were divided into two, namely primary book and secondary book of hadith. The primary book of hadith is the one written by mukharrij of hadith itself, and the sanad got to Prophet Muhammad. It can even reach friends (mauqūf) or tabi'in (maqțū '). The examples of these hadith are al-Kutub al-Sittah (hahih al-Bukbairi,

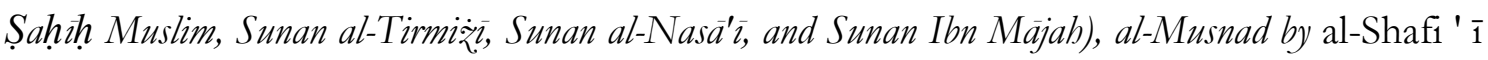
(w. 204 AH), Aḥmad bin Hanbal (w. 241 AH), Abū Ya'lā al-Maușilī (w. 307 AH), Șaḥịh Ibn Khuz̧aimah (w. 311 AH), Șaḥị Ibn Ḥibbān (w. 354 AH) ), al-Syamä'il al-Muhammadìyah by alTirmiżì (w. 279 AH), al-Ma'äjim al-saläsah (al-Mu'jam al-Kabìr, al-Mu'jam al-Ausat, and al Mújam al-Sagì by al-Ṭabarānī (w. 360 AH), al-Musnad by Aḥmad bin HAnbal (w. 241 AH), al-Mustadrak 'alà al-Ṣahịhain by Abū' Abdillāh al-Ḥàkim (w. 405 AH), al-Adāb by al-Baihaqī (d. 458 H), 'Amal al-Yaum wa al-Lailah by al-Nasā'î (d. 303 H) and Ibn Sunn̄̄ (d. 264 AH). Book of al-Arbai fì al-jihäd wa al-Mujäbidin by Ibn al-Muqri' (d. $618 \mathrm{H})$, and many more.

While the secondary book of hadith or anthology was the book taken or quoted from the primary ones. For example, Miskāh al-Mașäbih by al-Bagawī (w. $516 \mathrm{AH}$ ), this book was

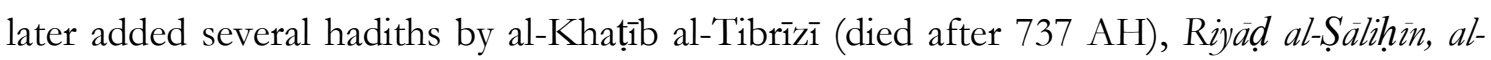

\footnotetext{
${ }^{4}$ Zahw, Muḥammad Abū., al-Hadìs wa al-Muhaddisūn (Mesir: al-Maktabah al-Taufīqīyah li al-Ṭab’i wa al-Nasyr wa al-Tauzī, t. th), p. 244. See Muḥammad 'Abdur Rạ̣īm dalam 'Abdullāh bin Muslim bin Qutaibah al-Dainūrī, Ta’mīl Mukhtalif al-Hadìis (Beirut: Dâr al-Fikr, 1415 H/1995 M), p. 5.

${ }_{5}$ Al-Kutub al-Sittah is the term used for the six main books, namely Sahịh al-Bukhari, Sahịh Muslim,

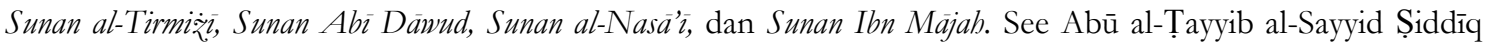
Hasan Khān al-Qanūjī (w. 1307 H), al-Hițțah fì Żikr al-Sịhāh al-Sittah, establishment by 'Alī Hasan al-Halabī (Beirut: Dār al-Jīl dan Ammān: Dār al-'Ammār, t.th). Syahbah, Muḥammad Abū., Fì Rịhāb al-Sunnah al-Kutub al-Sịhạh al-Sittah (Kairo: Silsilah al-Buhūì al-Islāmīyah, 1415 H/1995 M).
} 
Arbaīn by al-Nawawī (w. 676 AH), al-Matjar al-Räbih fì Śawāb al-'Amal al-Sälih by Syarafuddīn al-Dimyāțī (w. 705 AH), al-Muharrar fì al-Hadìs by Ibn 'Abd al-Hādī (w 744 AH), al-Jāmi 'al-ragìr fì Ahādìs al-Basyir al-Nażìr by al-Suyūṭī (w. 911 AH / 1505 AD), Bulūg al-Marām min Abdillah al-Ahkām by Ibn Hajar al-'Asqalānī (w. 852 AH), al-Nawāhì fì alȘahihhain by As'ad Muḥammad al-Ṭayyib, Mukhtär al-Ahädïs al-Nabawīyah wal al-Hikam alMuhammadīyah by al-Sayyid Aḥmad al-Hāsyimī, al-Tāj al -Jāmi 'li al-Ușūl fì Ahāaìis al-Rasūl by Manșūr' Alī Nāṣif, al-Targīb wa al-Tarbīb by al-Munżirī (581-656 AH), and many more. The book last mentioned would be discussed in this study.

\section{Al-Munżirī and Book of Al-Targīb wa Al-Tarhīb}

\section{Biography of al-Munżirī}

Al-Munżirī's full name is Zakīyuddīn Abū Muḥammad 'Abdul' Aẓīm bin 'Abdul Qawī bin Salāmah ibn Sa'ad al-Munżirī al-Syāmī al-Mișrī, with the deceased Abū Muhạmmad. He was born in Sya'bān in 581 AH / 1185 AD. Al-Munżirī was a religious scholar, he had a strong memory, and was very pious in his time, and he could differentiate between sabih and daif. In science of hadith, he was one of scholars who mastered the science of al ilal, garib, aljarh wa al-ta'dìl, and many things related to hadith. In addition, al-Munżirī is also known as the one who was expert in history, figh and Arabic language. In the field of hadith, he had degree of al-hāfiz because he could memorize and understand the branches of hadith science. Al-Munzirī traveled a lot in search of knowledge (rihlah fi țalab al-ílm), such as Makkah, Damascus, Ḥarrān, Ruhā, and Iskandariah.

Among the teachers of al-Munżirī are Abū al-Qāsim 'Abdur Raḥmān bin Muḥammad al-Qurasȳ̄ bin Warrāq, Abū' Abdullāh al-Artāḥ̄i (w. 601 AH), 'Abdul Majid bin Zuhair, Muhammad bin Saīd al-Ma'mūlī, al-hāfiz 'Alī bin al-Mufaḍḍal al-Maqdisī, al-Muțahhar bin Abū Bakar al-Baihaqī, Rabì'ah al-Yaman̄̄, Abū' Abdullāh bin al-Bannā ', Ibn Qudāmah, Abū Ḥafṣ' Umar bin Muḥammad (known as Ibn Ṭabarzad), Muhammad ibn Wahab bin alZìq, Khaḍir bin Kāmil, Abū al-Yaman al-Kindī, and many more. Among the students of alMunżirī are Abū 'Abdullāh al-Qazzāz, Ismā'īl bin Nașr, Ibn Daqīq al-'Īd (w. 702 AH), Ibn Khallikān (w. 681 AH), Syarafuddīn' Abdul Mu'min bin Khalaf al-Dimyāṭ̣̂, Abu al-ainusain al-Yūnīnī (w. 701 AH), etc. while the works of al-Munziri was Mukbtașar Sunan Abü Däwud named al-Mujtäba, Mukbtașar Șaḥ̆h Muslim, Syarh al-Tanbīh by al-Shīrāzī which is a fiqh of

${ }^{6}$ Biografi al-Munżirī, penulis ambil dari Abū Nașr 'Abdul Wahhāb bin 'Alī bin 'Abdul Kāfĩ or known as Tājuddīn al-Subkī (w. $771 \mathrm{H}$ ), Ṭabaqāt al-Syāfi'ȳah al-Kubrā, establishment by 'Abdul Fattāḥ Muḥammad alHulwa dan Mạ̣mūd Muḥammad al-Ṭannāḥ̄i, jilid-VIII (Mesir: Dār al-Iḥyā’ al-Kutub al-'Arabīyah), p. 259266. The Biography of al-Munżirī has take from Muhammad Muhyiddīn 'Abdul Hamīd, on muqaddimah tahquiq in al-Targīb wa al-Tarbīb (Beirut: Dār al-Fikr li al-Ṭibā'ah wa al-Nasyr, cet-II, 1393 H/1973 M), p. 7-8. Sa`̄id Muhammad Lahhāām, al-Targìb wa al-Tarbìb (Beirut: Dār al-Fikr li al-Ṭibā'ah wa al-Nasyr, cet-I, 1414 H/1993 M), p. 5-6. 'Abdul 'Azīz al-Jindī, muqaddimah tahquiq al-Targīb wa al-Tarbīb (Kairo: Dār al-Hadīì, 2007 M), p. 5-6. Ibrāhīm Syamsuddīn, muqaddimah tahqìq al-Targìb wa al-Tarbìb (Beirut: Dār al-Kutub al-'Ilmīyah, cet-II, 1426 H/2005 M), p. 4. Muqaddimah taḥqīq Yusrī 'Abdul Ganī dalam al-Munżirī Kifäyah al-Ta'abbud wa Tuhfah alTaz̧abhud (Beirut: Dār al-Kutub al-'Ilmīyah, 1407 H/1987 M). 
Syafi'i school, Mu'jam al-Syuyūkh, Arba'ūn Ḥadīsan, Kifāyah al-Muta'abbid wa Tuḥfah alMutazahhid, and of course also al-Targīb wa al-Tarhīb.

Al-Munziirī possessed good spirituality; he always worshiped to Allah and kept relationship among humans. In carrying out Allah's commands, al-Munżirī never ignored compliment or mocking of people towards him. He didn't feel delighted when praised, and discouraging when criticized. In morality context of Sufism, this behaviour is a good moral.

The sixth and seventh centuries is the time of progress in Islamic sciences, such as interpretations, fiqh, ushul fiqh, history, mysticism, natural sciences, including hadith. Some scholars who lived in al-Munirir era were al-Tibrīzì (w. 621 AH / 1224 AD), al-Rāfi'ì (w. 623 AH), Ibn al-Șalāḥ (d. 643 AH), al- Diyāa 'al-Maqdisī (w. 643 AH),' Izzuddīn Ibn 'Abd alSalām (w. 660 H), al-Nawawī (w. 676 H), Syamsuddīn Muḥammad bin Aḥmad al-Mauṣulī (w. $656 \mathrm{AH}$ ), the author of Safwah al-Rāsikh fì 'Ilm Mansükh wa al-Nāsikeh, Abū Syāmah alMaqdī (w. 665 AH / 1267 AD), Ibn al-Sā'ì (w. 674 AH), Ibn Khallikān (w. 681 AH).

After devoting himself to society and science by creating good works and intelligent students, al-Munżiri finally died on the 4th of Zulqa'dah, 656 AH / 1258 AD. This year was the great disaster for Muslims, namely the collapse of 'Abbasiyah Dynasty from attack of the Mongols led by Hulagu Khan. This was related to the socio-political life of alMunżirī.

\section{Socio-Political Situation}

Al-Munzirin lived at the end of 'Abbasiyah Dynasty, even the year of his death was the same as the year of the collapse of dynasty, $656 \mathrm{AH} / 1258 \mathrm{AD}$. The cause of collapse is due to the dispute among members of family. Abu Mūsā Muhammad al-Amīn appeared during the struggle for power (w. 193 AH). From 193 to 256 AH, there had been replacements ten times of Caliphate. Conflict among siblings could not be avoided between al-Amīn (w. 193 H) and al-Ma'mūn (w. 218 AH / 833 AD), then between al-Mutawakkil and al-Muntașir (247 AH). ${ }^{7}$ When viewed from the time of birth to death, al-Munzirī lived during the disintegration of the Abbasiyah dynasty (1000-1250 AD).

Disintegration in politics occurred at the end of Umayyah Dinasty. Umayyah's territory, since its establishment until its collapse was very extensive. It even reached Europe countries, like Spain and all of North Africa, except Egypt which was only temporary. This was different from Abbasiyah dynasty which did not reach the land of Europe; even many areas were not fully controlled. In its history, the relationship between the caliphate and provincial governors of his power was marked by tribute payments. ${ }^{8}$

Since the beginning of Hārūn al-Rashid's government (786-809), the problem of succession was very critical. He inherited the throne of Caliphate to his oldest sons, al-

${ }^{7}$ Hasyim, Muh. Fathoni., Pemikiran Hukum Islam Imam Al-Bukhari (Yogyakarta: Pustaka Pelajar, cet-I, 2013), p. 40.

${ }^{8}$ See Yatim, Badri., Sejarah Peradaban Islam (Jakarta: PT Raja Grafindo Persada, cet-VII, 1998), p. 63. 
Amīn and al-Ma'mūn. After Hārūn passed away, al-Amīn tried to betray his younger brother and appointed his son as his future successor. Then the civil war happened. AlAmīn was supported by Abbasiyah's military in Bagdad, while al-Ma'mūn had to struggle to liberate Khurasan to get support from Khurasan's war troops. Al-Ma'mūn succeeded in defeating al-Amīn, then became caliphate in 813. As a result of this incident, 'Abbasiyah military power weakened, even Iraqis and their provinces also weakened. ${ }^{9}$

The destruction of Abbasiyah dinasty was a political, social and economic change. This change resulted in the birth of small countries that replaced a large empire that had been in charge before. According to W.M. Watt - as quoted by Badri Yatim -, there were three factors that led to the collapse of Abbasiyah dynasty which shaped a new ruler and government; First, the extent of Abbasiyah dynasty territory, while communication between central government and regions was very difficult. In addition, mutual trust among the elite and government executives was very low. Second, the dependency of Caliphate on army was very high. Third, the finance of state was very difficult because the cost of army was very big. When military power was declining, the Caliphate was unable to force tax shipment to Bagdad. ${ }^{10}$

Abbasiyah authority and city of Baghdad were wiped out in 1258 when the Mongols invaded Islamic territory. They conquered Persia, Iraq and threatened people inappropriately. For 40 days, the Mongols succeeded in executing nearly all people of Bagdad. Libraries were burned, cities were destroyed, and the practice of Islamic law was banned under the Mongol law. ${ }^{11}$

According to Watt, the collapse of 'Abbasiyah dynasty occurred at the beginning of the ninth century. This phenomenon coincided with the coming of leaders who had military power in certain provinces that make them independent. ${ }^{12}$ The intellectualacademic tradition in Egypt at that time was very good. Some schools were also established by the government. Some madrasahs established in the year of 656 were; Madrasah Zähirìyah, founded by King Baibaras al-Bandaqdārī, Madrasah Kämiliyah, founded by Raja alKāmil in 621 AH. This madrasah was controlled Abū al-Khaț̣̄āb 'Umar bin Dihyah (w. 633 AH), then by Ibn Daqī al-' $\mathrm{I} d$ (w. $702 \mathrm{AH}),{ }^{13}$ that is al-Munżiri's student.

\section{Getting to know Book of al-Targīb wa al-Tarhīb}

In relation with book of al-Targib wa al-Tarbib, there are some points to discuss as follows:

\footnotetext{
${ }_{9}^{9}$ Lapidus, Ira M., A History of Islamic Societis (Cambridge: Cambridge University Press, 1988), p. 193194.

10 Yatim, Badri., Sejarah Peradaban Islam, p. 66-67.

${ }^{11}$ Emerick, Yahiya., The Complete Idiot's Guide to Understanding Islam (New York: Penguin Group, 2006), p. 347. Tamim Ansary, Destiny Disrupted: A History of the World through Islamic Eyes (United State: Public AffairsThe Perseus Books Group, 2009), p. 250-263.

${ }^{12}$ Yatim, Badri., Sejarah Peradaban Islam, p. 64.

13 'Azīz, 'Umar Muḥammad Sayyid 'Abdul., Ușūl al-Fiqh 'inda Ibn Daqiq al-İd min Khiläl Kitäbaih Iḥkām al-Ahkām Syarh 'Umdah al-Ahkeàm wa Syarh al-Ilmām (Kairo: Dār al-Salām li al-Ṭibā’ah wa al-Nasyr wa alTauz $\overrightarrow{1}$, cet-I, $1431 \mathrm{H} / 2010 \mathrm{H})$.
} 


\section{The History of Book Writing}

The full name of this book is al-Targïb wa al-Tarbib min al-Hadïs al-Syarif. Some hadith scholars added the word al-Nabawi before the word al-Syarif, so it became al-Targib wa alTarbib min al-Hadïs al-Nabawi al-Syarif. The first name mentioned was the most popular among scholars. The history of writing a book was usually associated with the motivation of the author, or things that became the background of writing. Some classical scholars and medieval scholars did it so that the motivation of writing the book was found out. This was also conducted by al-Munziri in book of al-Targib wa al-Tarbib. In introduction part of the book, he said:

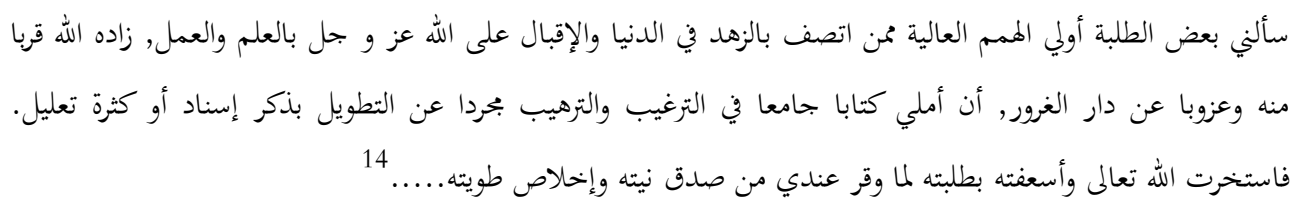

From the above quotation, it is known that the writing of book al-Targib wa al-Tarbib is not an idea directly coming from al-Munżirī, but from one of his students' request. The student was very pious, ideal, and faithful to God. The student's request was not easily granted by al-Munziirī, but he tried to ask for god's will. After that, he wrote the book of alTargib wa al-Tarbib since he saw his student really had sincere intentions in giving charity. The history stated that many scholars wrote a book due to external motivation.

Book of al-Targib wa al-Tarbib is one of books that explain about moral and ethics because it's more dominant. Viewed from the material and topics of hadith discussed, the writing of this book focused more on the things that must be done by Muslims in the world and hereafter to achieve happiness. The history of writing the book was to encourage Muslims in order to do good things and avoid all things forbidden in Islamic teaching.

In relation with the publication or printing of this book, the author found four versions; First, Beirut publishing: Dār al-Fikr li al-Ṭibā’ah wa al-Nasyr, second edition, 1393 AH / 1973 AD, consisting of 6 (six) volumes, corrected by Muhammad Muhyiddīn 'Abdul Hamīd. In addition to correcting, he also explained some words difficult to understand in the form of ta'liq and hassyiah. Both terms are one of forms of explanation of hadith which is known as syarh. Second, Beirut publishing: Dār al-Fikr li al-Ṭibā'ah wa al-Nasyr, first edition, 1414 AH / 1993 AD, consisting of 5 (five) volumes, corrected by Sa'ìd Muḥammad Laḥhāam, and reviewed by Maktab al-Buhụūs wa al-Dirāsāt. The final volume of this publication is the list of book content, written by Șidqī Jamīl al-'Aț̣āar, Beirut: Dār alFikr, 1415 AH / 1995 AD. This greatly facilitates in search for hadith and names of friends, because they were arranged alphabetically.

${ }^{14}$ Al-Munżirī al-Targīb wa al-Tarbīb, Kairo: Dār al-Hadīì, 2007 M), p. 7. 
Third, Egypt publishing: Dār al-Hadīìs, 2007 AM, corrected by Farīd 'Abdul' Azīz alJindī, in his Muqaddimah al-Tahqiq towards the book of al-Targīb wa al-Tarbīb (Egypt: Dār alHadìs, 2007 AD) In this publishing, the correctors re-check all the words of hadith to minimize the mistakes and evaluate the quality of hadith. In that case Farīd 'Abdul' Azīz referred to the book of Majma 'al-Zawä'id wa Manba' al-Fawa'id by al-Haisiamī, the assessment was by Aḥmad Syākir and Muḥammad Nāṣiruddīn al-Albānī (w. 1420 AH / 1999 AD). This edition consists of 2 (two) volumes, each volume consisting of 2 (two) sections, so the total number is 4 (four) sections. Fourth, Beirut publishing: Dār al-Kutub al'Ilmīyah, second edition, 1423 AH / 2003 AD, corrected by Ibrāhīm Syamsuddīn. This edition consists of 4 (four) volumes, it's then put together in one volume under the same publisher, second edition, $1426 \mathrm{AH} / 2005 \mathrm{AD}$.

\section{Source of Book Writing}

It was known that al-Munżirī is a medieval hadith scholar who lived at the end of the 6th century / 12AD until the mid of 7th century (581-656 AH). It was clear that he wrote the book of al-Targib wa al-Tarbib by quoting the hadith from the previous primary books. Especially the books that appeared in the 3rd century / 9 AD, which was the golden age of the hadith codification. During al-Munjiri's era many hadith books were written by hadith scholars in various forms. In fact, there were many comments either on the books of hadith or syarh, which can be references used by al-Munżirī writing book.

Al-Munżirī himself mentioned that the sources of writing the book of al-Targï wa alTarbìb were al-Muwatța 'by Mālik bin Anas (w.179 AH), al-Musnad by Aḥmad bin balanbal (w. 241 AH / 855 AD), al-Jāmi 'al-Sahịh by al-Bukhārī (w. 256 AH), al-Jāmi' al-Șahịh by Muslims (w. 261 AH), al-Sunan and al-Marāsil by Abū Dāudud (w. 275 AH / 889 AD), alSunan and 'Amal al-Yaum wa al-Lailah by al-Nasā'i (w. 303 AH / 915 AD), al-Sunan by Ibn Mājah (w. 275 AH), al-Mu'jam al-Kabir, al-Mu'jam al-Ausat, and al-Mu'jam al-Sagìr by alṬabarānī (w. 360 AH), al-Musnad by Abū Ya'lā al-Maușulī, al-Musnad by Abū Bakr alBazzār, al-Ṣaḥ̆h by Ibn Hibbān al-Bustī (w. 354 AH), al-Mustadrak 'alā al-Sahịhain by Abū' Abdullāh al-Ḥākim al-Nīsābūrī (w. 405 AH). In addition to these books, al-Munīirī also took hadith from al-Sahih by Ibn Khuzaimah (w. $311 \mathrm{AH}$ ), the books of Ibn Abi al-Dunya (w. 281 AH / 894 AD), Syu'ab al- Imān and Book of al-Zubd by al-Baihaqī (w. 458 AH), and al-Targīb wa al-Tarbīb by Abū al-Qāsim al-Așbahānī. ${ }^{15}$ After reviewing carefully, it was known that al-Munżirī also referred to Musnad al-Firdaus by Abū Manșūr al-Dailamī, Book of al-Arba'īn by Abū 'Abdur Raḥmān al-Sulamī.

\section{Procedures of Book Writing}

There were several procedures of al-Munziri in writing book of al-Targib wa al-Tarbib: First, mentioning the first sanad and matan of hadith. The meaning of the first sanad here is a fellow who narrated the hadith, because without them it is impossible for the hadith to get

\footnotetext{
15 Al-Munżirī, al-Targīb wa al-Tarbìb, p. 9.
} 
to us. Second, mentioning the last narrator. The meaning of the last narrator was the scholars who collected and write the hadith in their books or commonly called as mukharrij al-hadïs. Third, explaining the words that are difficult to understand or in mustalah al-hadïs it's known as alfäz garibah.

Fourth, mentioning the quality of hadith. There were two words that need to consider regarding the assessment of al-Munziri towards hadith in his book. If the hadith is sabih and basan, then it is mentioned with redaction 'an (from fellows ...). Likewise the mursal hadith, munqati ', mu'dal, there are mubham narrators, or are considered daif, but the others are siqah, or there are still narrators who are debated about their siqah. But in this case, al-Munzirī explained the problem of hadith which was related with the approach of the science of al-

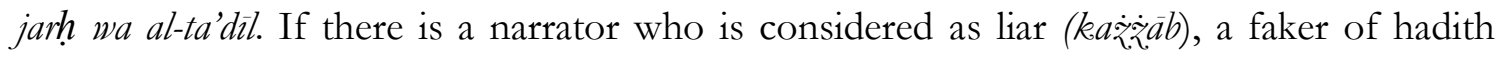
(wadd $\left.\bar{a}^{\prime}\right)$, accused of lying or a faker (muttaham), it is agreed to leave the hadith (mujma' 'ala

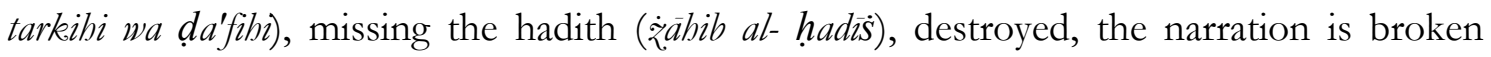
(bälik), sāqiț, laysa bi syai', very weak (ḍa'if jiddan), or da'if only, then the pronunciation used is rumiya (with bina 'majbü). Thus, there are two forms of history of daif hadith, namely with redaction of ruwiya, or without giving any comments.

\section{Method of Book Writing}

Book of al-Targib wa al-Tarbib was arranged based on the books (themes / main topics), then followed by chapters containing several hadiths. In addition to chapters, sometimes used term fasal. Actually al-Munżirī did not explicitly mention the chapters in his discussion, but directly mentioned with the words of al-Targib wa al-Tarbib. Before entering the main chapter, the book was begun with the preface of the author (muqaddimah almu'allif), the list of books and chapters (fibris kutub wa abwäb al-kitab), al-targìb fi al-ikblạs wa

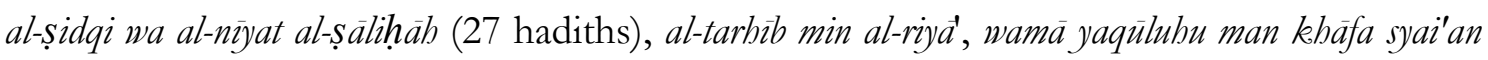
minhu (33 hadiths), al-targìb fi ittibä' al-kitäb wa al-sunnah, al-tarbib min tarki al-sunnah wa irtikäb al-bida 'wa al-ahwä' (16 hadiths), al-targïb fì al-badä'ah bi al-khair li yustanna bibi wa al-tarbïb min al-badä'ah bi al-syarr khauf an yustanna bibi. Some of the book correctors directly included the hadiths in book of niyat, without any details correction as the authors mentioned.

In quoting every hadith, al-Munziirī mentioned the first sanad, that is a fellow, then mentioned mukharrij or the narrator of the last hadith. Sometimes the quality of hadith is mentioned, and explains some words that are difficult to understand (al-alfäz al-garibah). Thus, al-Munżirī also conducted sharb of hadith of several words that are difficult to understand. In the history of hadith narration, the science of garib al-hadìi had transformed into the science of syarh. After that, al-Munzirī began his book with book of al-ilm. The details are as follows:

\begin{tabular}{ccccc}
\hline Chapter & No & Name of Book & $\begin{array}{c}\text { Number of } \\
\text { Chapter }\end{array}$ & $\begin{array}{c}\text { Number of } \\
\text { Hadith }\end{array}$ \\
\hline 1 & 1 & Kitäb al-Nìyat & 6 & 98 \\
& 2 & Kitäb al-Tlm & 11 & 141 \\
\hline
\end{tabular}




\begin{tabular}{|c|c|c|c|c|}
\hline \multirow{11}{*}{2} & 3 & Kitāb al-Ṭahārah & 13 & 120 \\
\hline & 4 & Kitāb al-Ṣalāh & 40 & 484 \\
\hline & 5 & Kitāb al-Nawāfil & 20 & 186 \\
\hline & 6 & Kitāb al-Jumu'ah & 7 & 76 \\
\hline & 7 & Kitāb al-Sadaqāt & 18 & 340 \\
\hline & 8 & Kitāb al-Ṣaum & 22 & 196 \\
\hline & 9 & Kitāb al-İdain wa al-Uḍiyah & 4 & 23 \\
\hline & 10 & Kitāb al-Hajj & 16 & 192 \\
\hline & 11 & Kitāb al-Jihād & 15 & 272 \\
\hline & 12 & Kitāb Qiräab al-Qur'ān & 15 & 96 \\
\hline & 13 & Kitäb al-Żikr wa al-Du'a'' & 24 & 311 \\
\hline \multirow[t]{8}{*}{3} & 14 & Kitāb al-Buyü' wa Gairihä' & 18 & 321 \\
\hline & 15 & $\begin{array}{c}\text { Kitāb al-Nikēh wa mā } \\
\text { Yata'allaqu bibi }\end{array}$ & 14 & 169 \\
\hline & 16 & Kitäb al-Libās wa al-Zinah & 13 & 115 \\
\hline & 17 & Kitāb al-Ṭa'àm wa Gairibi & 10 & 83 \\
\hline & 18 & Kitäb al-Qaụd"' wa Gairibi & 11 & 191 \\
\hline & 19 & Kitāb al-Hudūd wa Gairihā & 14 & 242 \\
\hline & 20 & $\begin{array}{c}\text { Kitāb al-Birr wa al-Silah wa } \\
\text { Gairihimāa }\end{array}$ & 12 & 235 \\
\hline & 21 & Kitāb al-Adab wa Gairibi & 29 & 680 \\
\hline \multirow[t]{5}{*}{4} & 22 & Kitäb al-Taubah wa al-Zubd & 11 & 363 \\
\hline & 23 & $\begin{array}{c}\text { Kitäb al-Janā'iz wa mā } \\
\text { Yataqaddamubā }\end{array}$ & 21 & 367 \\
\hline & 24 & \multirow{3}{*}{$\begin{array}{c}\text { Kitāb al-Ba’’ wa Abwäl Yaum } \\
\text { al-Qiyämah, } \\
\text { Kitāb Șifat al-Jannah wa al- } \\
\text { Nār } \\
\text { Total Number }\end{array}$} & & \\
\hline & 25 & & 37 & 231 \\
\hline & & & & 5532 \\
\hline
\end{tabular}

From the explanation above, it can be said that the book of al-Targib wa al-Tarbib by Munżirī is one of the encyclopedic books because it contains many hadiths. This book contains a variety of hadith that can be used as a guidance for Muslims in their life, in all aspects such as worship, morals, economics, politics, and so on. The point is that the hadith contained in the book cover many aspects. This is the uniqueness and strength of the book of al-Targib wa al-Tarbib. Although not all hadiths in the book are sabih or hasan, but there are also some hadiths that are daif. For the author, the assessment of the hadith is authentic, hasan, and daif is subjective because each scholar has different standards in evaluating a narrator.

Please note that book of al-Ba's wa Ahwäl Yaum al-Qiyamah, some correctors put it together in one book with book of Sifat al-Jannab wa al-När. This is in line with the corrector of book of hadith of Egypt publishing: Dār al-Hadìì. Some others separated it, as published by Beirut: Dār al-Kutub al-'Ilmìyah. 


\section{Book Position in Hadith Literature}

Book of al-Targib wa al-Tarbib can be categorized into moral book, because the contain is more dominant than other problems. When compared with anthology or secondary books such as Riyạ̈̆ al-Șalihìin by al-Nawawī (w. $676 \mathrm{AH}$ ), al-Targïb wa al-Tarbib was not very influential. It can be seen from the response or appreciation of the scholars towards the book that it got view comments. No scholar gave syarb to book of al-Targib wa al-Tarbib. In contrast to Riyaạd al-Sälihìn, it had been proposed by several scholars, such as Ibn 'Allān alȘiddīqīq (996-1057 AH) and Muhammad bin Șālị̣ al-'Us̉aimīn (1347-1421 AH).

We need to know that the book of al-Targib wa al-Tarbib is not a primary book, but it is a secondary or anthological book that cited the previous primary books. Even though there were no scholas who condemned it, the book of al-Targib wa al-Tarbib was still studied by certain groups. It seemed that the differences in schools or regions also affect the distribution of one's work. Although al-Munziiri had many students, none of them gave syarah to the book.

Previous scholars were trapped in the study of sanad, so the standard of acceptance and rejection of hadith was judged from a narrator even though his faith was in accordance with the general teachings of Quran. Some scholars who are sanad oriented indeed expressly rejected the practice of daif hadith in all respects. Like al-Albānī (w. 1999 AD) in book of Silsilah of al-Ahädïs al-Sahihah and Silsilah al-Ahädïs al-Daîfah. It must be admitted that the study of sanad is indeed important because it convey us to matan or hadith texts. If only relying on sanad without considering text and context, there will be many unused hadith. Therefore, a neutral opinion is daif hadith and it can be actualized with certain conditions as explained in the literature of muștalah al-ḥadis.

\section{Critical Comments toward the Book}

A work or thought was not created in an empty space of culture, including the book alTargib wa al-Tarbib. As already stated that the book was written by al-Munżirī because of the request of one of his students. One of the scholars of hadith who examined the book alTargib wa al-Tarbỉb was Muḥammad Nāṣiruddīn al-Albānī (w. 1420 AH / 1999 AD). ${ }^{16}$ He

16 some scholars who have rejected al-Albani's ideas include Ismā’̄il bin Muḥammad al-Anșārī, 'Abdullāh bin Șālih al-Abīlān, Fahad bin 'Abdullāh al-Sanīd, 'Abdul 'Azīz bin 'Abdullāh bin Bāz, 'Ādil bin 'Abdullāh al-Saīdān, Dr. Șāliḥ bin 'Abdul 'Azīz 'Ālu al-Syaikh, 'Abdullāh bin Muḥammad al-Darwīsy, Hamūd bin 'Abdullāh al-Tuwaijirī, Bakar bin 'Abdullāh Abū Zaid, 'Abdul Qādir bin Habībullāh al-Sindī, Dr. Ibrāhīm al-Ṣabīḥ̄, Muștafā al-'Adawī, 'Abdullāh bin Māni’ al-'Utb̄̄, Khālid bin Aḥmad al-Muażżin, 'Abdullāh bin 'Abdur Raḥmān al-Sa’ad, 'Abdul Fattāḥ Mạ̣mūd Surūr, dan lain-lain. Sedangkan di luar kalangan SalafiWahabi adalah Ḥasan bin 'Alī al-Saqqāf, 'Abdul Mun'im Muṣṭafā Halīmah, 'Abdul Fattāḥ Abū Guddah, Badruddīn Hasan Dayyāb al-Dimasyqī, As’ad Sālim Tayyim, Mạ̣mūd Sa’̄̄d Mamdūḥ, 'Abdul 'Azīz bin alȘiddīq al-Gumārī, 'Abdullāh al-Ḥabsyī al-Harawī, Mamdūḥ Jābir 'Abdus Salām, Aḥmad 'Abdul Gafūr 'Ațtāar, Dr. 'Alī 'Abdul Bāsiṭ Mazīd, Hassān 'Abdul Mannān Maḥmūd al-Maqdisī, Prof. Dr. Șalāḥuddīn al-Idlibī, 
examined the book and found several daif hadiths or those in the science of mustalah alhadis called the maudū'. One if characteristics of the maudu 'hadith is that there are narrators who are considered as faker/liar. There are two books of al-Albani that discussed

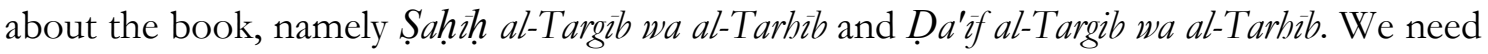
to know that these two books that are still patterned in the study of sanad, less paid attention to matan of hadith. But sometimes al-Albani is inconsistent with his assessment. In book of Da'îf al-Targib wa al-Tarhīb, hasan hadith was also included. ${ }^{17}$

Although book of al-Targīb wa al-Tarbìb had been studied by al-Albānī, but its assessment is still doubted by some scholars. That is one reason why Hasan bin 'Alī al-

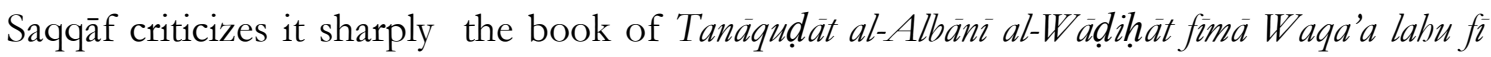

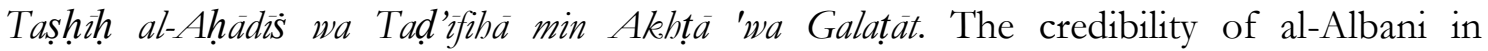
evaluating hadith is indeed recognized by some scholars, including Yūsuf al-Qarāọāwī (l. 1928) acknowledged that al-Albānī was indeed an expert in the field of hadith.

There are several examples that need to be written in this paper, namely sabih, hasan, and daif hadith with various forms. Before al-Tirmiżìs era (w. 279 AH), some scholars only divided the quality of hadith into two, namely sabih and daif. But in al-Tirmizì’s era, he added the term hasan which later became famous among the scholars of hadith until now. ${ }^{18}$ One of al-Tirmizi's contributions in the science of hadith is to introduce many terms of hadith quality in his book, SunIan, one of which is the term basan. The examples of hadith contained in book of al-Targib wa al-Tarbib are:

\section{Sahih Hadith}

The meaning of sabib hadith here is a hadith whose sanad is continued, narrated by the one who is fair, dobit and siqah, there is no syaziz and illat. ${ }^{19}$ This definition is dealt in the science of mustalah al-hadis. Actually the assessment of whether the hadith is sabih, hasan, or daif is a very subjective matter even though it uses method of al-jarh wa al-ta'dil. The science of mustalah al-hadis is also very subjective since the one who judge other people might forget and be wrong in certain situations and circumstances. Nevertheless, the science of al-jarh wa al-ta'dil helped scholars of hadith to select the hadith of Prophet from narrators who are still intellectually doubtful and credible. One of examples of sabib hadith in book of alTargib wa al-Tarbib is:

Muḥammad 'Ārif al-Juwaijātī, et all. See Aswad, 'Abdur Razzāq, al-Ittijāhāt al-Mu'ạșirah fì Dirāsah al-Sunnah alNabawìyah fì Mișra wa Bilād al-Syām (Damaskus: Dār al-Kalim al-Ṭayyib, cet-I, 1429 H/2008 M).

${ }^{17}$ See al-Albānī, Muḥammad Nāṣiruddīn., Ḍ a'if al-Targìb wa al-Tarbīb (Riyāọ: Maktabah al-Ma’ārif li alNasyr wa al-Tauzî̀, cet-I, 1421 H/2000 M), p. 48.

18 al-Juyūsyī, Muḥammad Ibrāhīm., Dirāsāt Haula al-Sunnah (Dār al-Ittihāàt al-'Arabī, cet-I, 1396 H/1976 M), p. 5-6. Ḥāsyim, Aḥmad 'Umar., Qawā’id Ușūl al-Hadìs, (Beirut: Dār al-Fikr, t.th), p. 79.

19 Jamā’ah, Abū 'Abdillāh Badruddīn Muḥammad bin Ibrāhīm bin., al-Manhal al-Rawì fì Mukhtașar Ulūm al-Hadìs al-Nabawì, ditaḥīiq oleh al-Hūt, Kamāl Yūsuf., (Beirut: Dār al-Kutub al-'Tlmīyah, cet-I, 1410 H/1990 M), p. 41. al-Ṣāiḥ̣, Șubḥ̄̄., Ulūm al-Hadïs wa Muṣtalahuhu, (Beirut: Dār al-'Ilm li al-Malāyīn, cet-IX, 1977), p. 145. Hāsyim, Aḥmad 'Umar., Qawāìd Ușūl al-Hadìs, p. 44. 


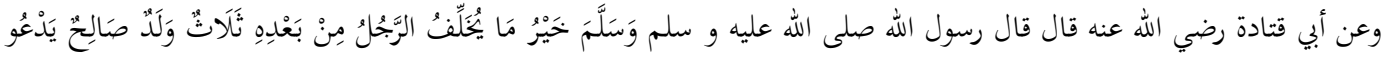

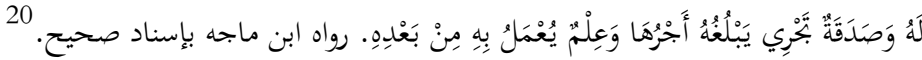

Al-Munzirī cited hadith about the importance of seeking for knowledge from Ibnu Majah in his Sunan, and said that the quality was sabih. Is it true? The complete sanad of the hadith is:

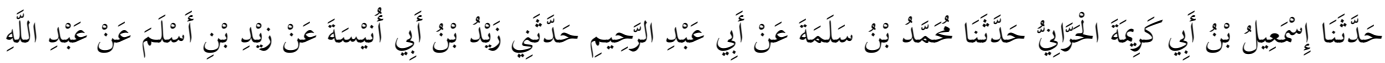

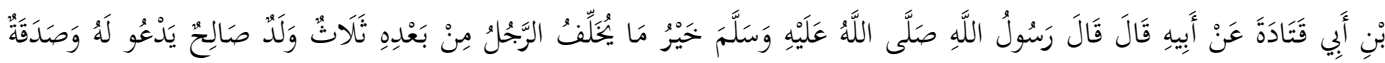

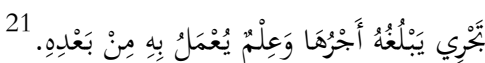

"Had told us Ismā'îl bin Abū Karīmah al-Ḥarrānī said, had told us Muhammad bin Salamah of Abū 'Abdurrahīm said, had told me Zaid bin Abū Unaisah from Zaid bin Aslam of' Abdullāh bin Abū Qatādah from his Father he said ; Rasulullah saw. said: "there were good things left by a man after his death; pious children who pray for him, charity whose reward reaches him and the knowledge practiced by people after his death".

The above hadith was narrated by Ibn Mājah (w. 273 AH) in his sunan, and the sanad is sabib because it fulfilled the five conditions of sabib hadith. In fact, the hadith does have several supporting traditions, as narrated by Muslims (w. 261 AH) in his Sahị. Hadith narrated by Ibn Mājah above is a motivation to educate children in order to be good children, not rebellious to parents, respect and help among others. The point is to have good morals and characters.

In addition, the hadith also encouraged us to diligently give charity, infaq, waqf, or doing things that are beneficial for the benefit of many people or community. The final point is that we study diligently, go seek for knowledge, and teach others to have benefits. These three things will get benefits even though the person concerned has died. This is a pride for Muslims who truly understand their religion. At present context, the hadith was used as the base for "tablil kematian" program for some people who were left to die by one of their family members. "tablil kematian" program usually runs for nine days, some also do it on certain days.

\section{Hasan Hadith}

Hasan hadith is almost the same as sabib hadith in terms of its existence, but the level is still under the sabib hadith. One of the factors is because there is a narrator that is less dobit. ${ }^{22}$

\footnotetext{
${ }^{20}$ Al-Munżirī, al-Targīb wa al-Tarbīb, jilid-I, juz-I (Kairo: Dār al-Hadīì, 2007 M), p. 78-79.

21 al-Qazwainī/al-Qazwīnī, Abū 'Abdullāh Muhammad bin Yazīd bin Mājah., Sunan Ibn Mājah, Kitāb alMuqaddimah, Bāb Śawāb Mu'allim al-Nās al-Kabir, no. 237.

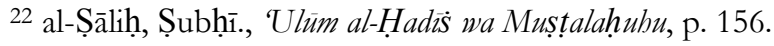

Diterjemahake saka: Basa Malaysia
} 
This is one of the problems in the science of hadith related to the problem of dobit of a narrator. Al-Tirmizi stated that hasan hadith is a hadith in which the narrator was not accused of lying and syàz: ${ }^{23}$ Al-Khattāāi $($ d. $388 \mathrm{H}$ ) called it a hadith whose source was clear and narrated by a person famous for the narration of hadith (má 'urifa makhrajubu wa isytahara rijälubu). According to him, this opinion was stated by the majority of scholars and used by fiqh scholars. ${ }^{24}$ Hasan hadith was also divided into two terms namely hasan lizäatibi and hasan ligairibi. Basically, hasan ligairibi is a daif hadith, but it has syähid and täbi', then the degree became hasan ligairibi. One example of the hasan hadith is:

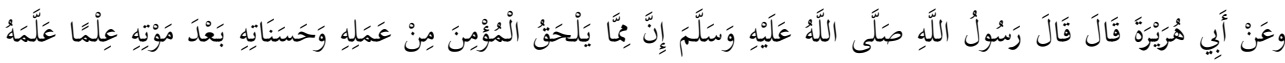

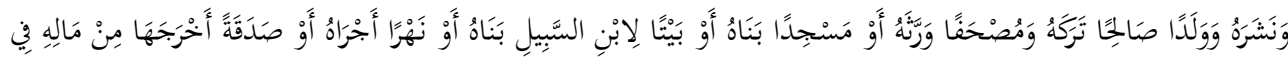

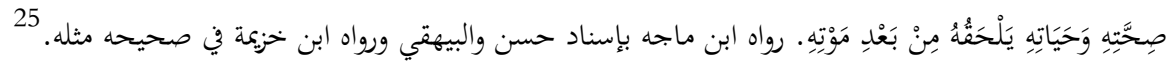

Al-Munżirī cited hadith about the importance of seeking for knowledge above from Ibnu Majah in his sunan, and said that the quality was sabib. Is it true? The full sanad of the hadith in Sunan Ibn Mäjab is:

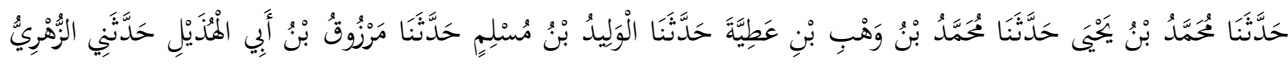

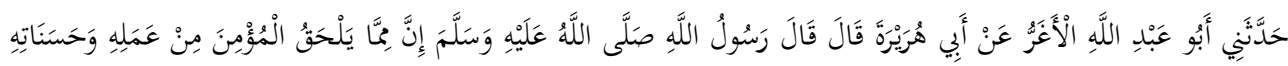

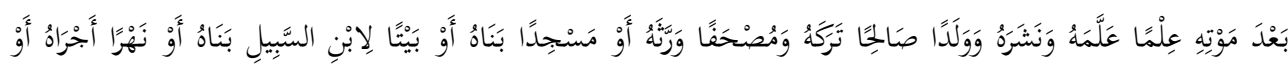

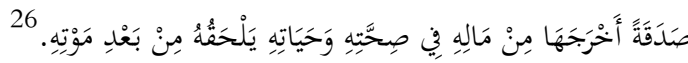

"Had told us Muhammad bin Yahyā said, had told us Muhammad bin Wahb bin 'Ațīyah said, had told us al-Walīd bin Muslim said, had told us Marzūq bin Abū Hużail said, had told me al-Zuhrī said, had told me Abū Abdullāh al-Agar of Abū Hurairah he said; Rasulullah saw. said: "Indeed, the good deed that will accompany a

$811 / 5000$

The hadith scholars divide dabit (ḍabț) into two namely ḍabit șadrī and ḍabit kitābī. Ḍabit ṣadrī means that a narrator adheres to a history that has been heard, and is able to convey to others whenever asked. Ulama agrees that a narrator who has dabit is as accepted as his history. Whereas the dabit kitābi means that a narrator preserves the record of his hadith in a book, preserving his hadith from any changes since it was narrated to others. The majority of scholars accept traditions from narrators who only have such hadith records ḍabiṭ kitābī. Only Abū Ḥanīfah (d. 80 H), Mālik (d. 179 H), and Abū al-Ṣaidalānī (d. 427 H) who did not receive dabit kitābī. The opinions of these three scholars are not accepted by the majority of hadith scholars. Syihābuddīn Abū al-Faḍal Aḥmad bin Alī bin Muḥammad al-Asqalānī al-Mișrī, al-Nukat alā Nuzhah al-Nazar fi Taudih Nukbbah al-Fikar, establishmet by Alī Hasan al-Halabī menambahkan catatan yang ditulis oleh al-Albānī terhadap kitab al-Nuz̧hah, (Riyāọ: Dār Ibn al-Jauzī, cet-I, 1431 H), p. 77. al-Khațīb, Muḥammad 'Ajjāj., Ușūl al-Hadìis: 'Ulūmubu wa Mușțalahubu (Beirut: Dār al-Fikr, cet-II, 1391 H/1971 M), p. 232. Ḥamādah, Fārūq., al-Manhaj al-Islāmi fì al-Jaṛ̣ wa al-Ta’dül (Kairo: Dār al-Salām), p. 173-174.

${ }^{23}$ Jamā'ah, Ibn., al-Manhal al-Rawì, p. 43, al-Malībārī, Ḥamzah bin 'Abdullāh., Naẓarāt Jadìdah fì 'Ulūm al-Hadìis (Beirut: Dār Ibn Hazm, cet-I, 1416 H/1995 M), p. 19. Umar Ḥāsyim, Aḥmad., Qawa’id Uṣül al-Hadïìs, p. 72 .

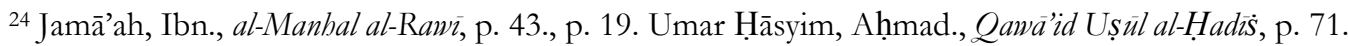

25 Al-Munżirī, al-Targīb wa al-Tarbīb, volume-I, chapter-I (Kairo: Dār al-Hadìì, 2007 M), p. 78.

26 al-Qazwainī, Ibn Mājah., Sunan Ibn Mājah, Kitāb al-Muqaddimah, Bāb Śawāb Mu'allim al-Nās al-Kahir, no. 238 . 
believer after he died was the knowledge he taught and spread, the pious child he left behind and the Quran he inherited, or the mosque he built, or the house he built for Ibn Sabil or the river that he flew (for other people), or the charity he gave from his possessions in his healthy life and his lifetime, all will accompany him after he died."

This hasan quality hadith had the same meaning as the sabib hadith above with some good deeds he made that were found by Muslims after his death. The above hadiths emphasized more on social charity. Humans are social beings who can not live alone, wish or not he must interact with other people to meet the needs of the world and hereafter. Islam regulates not only one's personal life, but also the lives of all beings on this earth. Therefore, humans must pay attention and protect the surrounding environment. Relationships to God, relationships to humans, relationships to the environment, plants, animals or animals must be considered. Thus, life will be safe, harmonious, peaceful, and certainly will benefit people who are still alive or has died.

\section{Daif Hadith}

Daif hadith is a hadith that doesn't fulfill the requirement of sabih and hasan hadith. ${ }^{27}$ All depends on sanad and narrator of hadith. From three qualities of hadith (sabih, hasan, daif), daif hadith has many branches or terms. The example of sahih hadith in book of al-Targī wa al-Tarbib is:

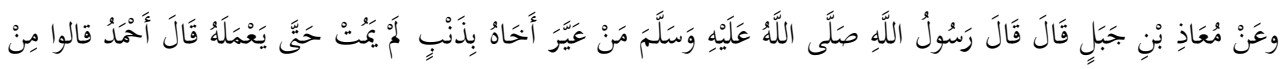

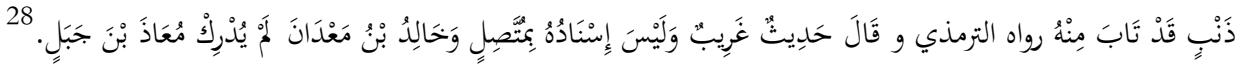

This hadith was cited by al-Munziirī from Sunan al-Tirmiżi that was assessed hasan garìb, yet it had trouble since Khālid bin Ma'dān never met Mu'āż bin Jabal. It meant that hadith cited by al-Munziri was not Prophet Muhammad's words, it could be the expression of narrator. This hadith was narrated by al-Tirmizi through line of sanad:

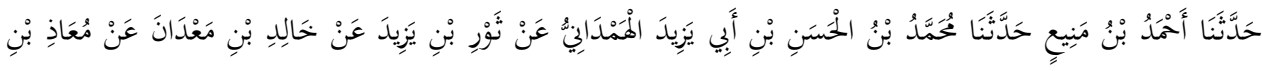

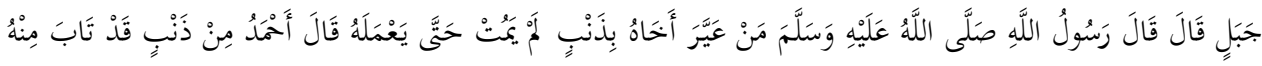

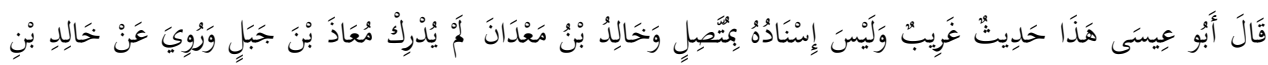

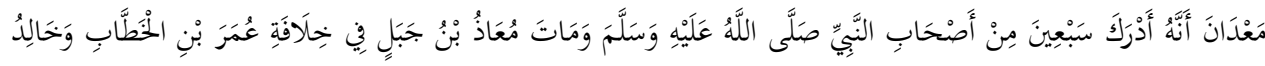

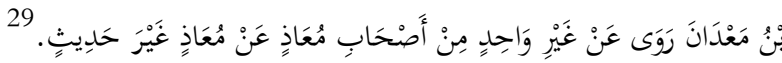

\footnotetext{
${ }^{27}$ Jamā'ah, Ibn., al-Manhal al-Rawī fì Mukhtașar 'Ulüm al-Hadïs al-Nabawì, p. 46. Șubḥ̄ al-Ṣāliḥ, 'Ulüm alHadìi wa Muștalahuhu, p. 165.

28 Al-Munziirī, al-Targìb wa al-Tarbīb, jilid-II (Kairo: Dār al-Hadīì, 2007 M), p. 301.

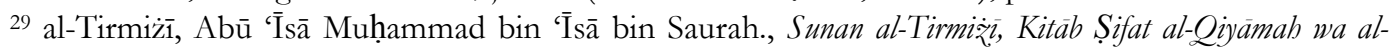
Raqūiq wa al-Wara', Bāb Sifat al-Qiyämah wa al-Raqā'iq wa al-Wara’, p. 2429.
} 
Had told us Ahmad bin Manī ', had told us Muhammad bin al-Hasan bin Abu Yazid al-Hamdani from Saur bin Yazid from Khalid bin Ma'dan from Mu'àż bin Jabal said: Rasulullah saw said: "Whoever tells bad things of his friend to others because of sinful deed he did, then he will not die until he did it. Ahmad said: The sinful deed which he has repented of. Abu 'Īsā said: This hadith is garīb, and the sanad is not continued, Khālid bin Ma'dān did not meet Mu'āż bin Jabal, and had been narrated from Khālid bin Ma'dān that he met seventy companions of Prophet, and Mu'àż bin Jabal died during the caliphate 'Umar bin al-Khaț̣āb, while Khālid bin Ma'dān had narrated many hadiths from many of Mu'àż's friends from Mu'āż.

The above hadith is indeed flawed in a sanad, but it is indeed important to pay attention in daily life. The lesson learnt of this phrase is that we are not allowed to mock others for their disgrace or sin. Someone who commits a sin, then he repents, then Allah will forgive him and raise his degree. But if someone continues to commit sin, to avoid harm then we may mock him in order that other people are not affected by sin. At present context, the hadith can be used as a proposition to not bully each other. The attitude of bullying sometimes have an impact on horizontal conflicts, therefore we may not mock each other. We must remind each other when seeing other people make mistakes.

There is no doubt although al-Munżirī was a scholar of hadith, the book of al-Targīb wa al-Tarbib still contains daif hadith with various forms. It does not mean that he does not understand the science of hadith, but the hadiths are included so that they are suitable with the topic or chapters of book contents. Daif hadith is still debatable among classical scholars until now. The debate emerged in the third century until now, even until the Day of Judgment. However, their debate is only on fadä'il al-a'mäl. Some scholars expand the scope of daif hadith, both the field of $m u^{\prime}$ amalah and others, especially in the field of faith.

\section{The Strength and Weakness of the Book}

We need to know that the strengths of al-Targib wa al-Tarbib book are (1). Facilitating someone in searching for hadith because it has been compiled based on certain chapters, (2). There is an explanation of some words which are difficult to understand, (3). Put the names of the first narrators as well as the last narrators, (4). Containing teachings related to life in the world and hereafter with various aspects. (5). Quoting hadith not only from mainstream hadith books such as al-kutub al-sittah but also from non-mainstream hadith books. While the weakness of the book are (1). Not all of hadith listed are from the Prophet, because some are from companions, and followers. (2). Not all hadiths are judged by al-Munżirī.

Although al-Munżirī was an expert in the field of hadith, when writing the book of al-Targib wa al-Tarbib, many flawed hadiths are included in the book. The flawed hadiths here mean the hadiths that are still doubted it authenticity, weather it really comes from the Prophet Muhammad or not. In hadith research, there are possibly four findings; (1). Sanad is sabih, the matan is also sabih, (2). Sanad is sabih, matan is daif, (3). Sanad is daif, matan is sabih, 
(4). Sanad is daif, matan is also daif. The four findings are common hasan hadiths can be included in category of sabih even though the level is still lower. Hadith scholars agree that basan hadith can be used as bujjah and be actualized.

\section{CONCLUSION}

There is no doubt that al-Munzirin has contributed in the study of hadith in the book of alTargib wa al-Tarbib. Regardless of whether all the hadith contained in the book are sabih, hasan, or daif with various types, it is clear that al-Munzirī has enriched the Islamic science. This book contains aspects of life in the world and hereafter, so it needs to be studied. So far, some scholars only discussed the hadith in terms of sanad without seeing the meaning of hadith content. Even though not all hadith considered daif, its matan was automatically rejected. There are some hadiths whose sanad is sabih, but their matan are rejected. The study of sanad is indeed still necessary, because without sanad, hadith will not get to us. In addition to the study of sanad, we must also pay attention to matan of hadith.

In relation to the book of al-Targīb wa al-Tarbib, al-Munżirī included too many hadiths related to the topics discussed. Therefore it is not surprising that many daif hadiths with their various types are included in the book. At present context, a study of matan needs to be studied seriously. In several Islamic Universities (STAI / STAIN, IAIN, UIN) studies of matan seem to have been started. This is a proof that there is a course of Ma'anil Hadith Science, in addition to the study of Living Hadith.

The study of hadith books is indeed necessary so that people know the literature of hadith of previous scholars. This can be conducted in the study of hadith at Universities. Hadith books have many forms, so it is necessary to study as an effort to appreciate the heritage of previous scholars. By studying a book, it will be known the writing context and the past socio-historical situation. This is in accordance with talents and personal abilities of hadith learners. By studying the book of hadith, the person as if lived in period of the author of the book itself. They even feel like living in the past, so they can feel two worlds, namely the world of the past and present.

Some hadiths contained in book of al-Targib wa al-Tarbib can actually be contextualized with the life of Muslims in general. This needs serious and thorough effort to study it. With the contextualization of meaning, the hadith texts can be practiced and not only stored or displayed on bookshelves. At least, the author has contextualized the three hadith texts exemplified in the book of al-Targib wa al-Tarbib.

\section{REFERENCES}

Abū Syahbah, Muḥammad, Fĩ Riḥāb al-Sunnah al-Kutub al-Sịhāh al-Sittah, Kairo: Silsilah alBuhūì̀ al-Islāmīyah, 1415 H/1995 M.

Abū Zahw, Muḥammad, al-Hadìs wa al-Muhaddisinn au Ināyah al-Ummah al-Islämīyah bi alSunnah al-Nabawiyah, Mesir: al-Maktabah al-Taufíqiyah li al-Ṭab’i wa al-Nasyr wa alTauzì , t.th. 
Millatī, Journal of Islamic Studies and Humanities, Vol. 4, No. 1, Juni 2019: 14-34

Albānī, Muḥammad Nāṣiruddīn, Da'îf al-Targz̄b wa al-Tarbìb, Riyāḍ: Maktabah al-Ma’ārif li al-Nasyr wa al-Tauzì', cet-I, $1421 \mathrm{H} / 2000 \mathrm{M}$.

Sahịh al-Targīb wa al-Tarbīb, Riyāẹ: Maktabah al-Ma'ārif li al-Nasyr wa alTauzì', cet-I, $1421 \mathrm{H} / 2000 \mathrm{M}$.

Amal, Taufik Adnan Islam dan Tantangan Modernitas: Studi atas Pemikiran Hukum Fazlur Rabman, Bandung: Penerbit Mizan, cet-V, 1414 H/1994 M.

Ansary, Tamim, Destiny Disrupted: A History of the World through Islamic Eyes, United State: Public Affairs-The Perseus Books Group, 2009, edisi bahasa Indonesia, Dari Puncak Bagdad: Sejarah Dunia Versi Islam, trj. Yuliani Liputo, Jakarta: Zaman, cet-II, 2012.

Anshori, Muhammad, "Ketersambungan Sanad Dalam Periwayatan Hadis: Analisis Terhadap Hadis Mu'allal', dalam Muhammad Alfatih Suryadilaga, ed. Ilmu Sanad Hadis, Yogyakarta: Idea Press, cet-I, 2017.

Ḥākim, Abū 'Abdillāh Muḥammad bin 'Abdullāh al-Naisābūrī, Ma'rifah Ulūm al-Hadìs, ditashih dan dita'liq oleh al-Sayyid Mu’żim Husain, Kairo: Maktabah al-Mutanabbī, t.th.

Ḥāsyim, Aḥmad 'Umar, Qawā’id Uṣūl al-Hadīs, Beirut: Dār al-Fikr, t.th

Hasyim, Muh. Fathoni, Pemikiran Hukum Islam Imam Al-Bukhari, Yogyakarta: Pustaka Pelajar, cet-I, 2013.

Ibn Jamāah, Abū 'Abdillāh Badruddīn Muhammad bin Ibrāhīm, al-Manhal al-Rawì fì Mukbtașar Ulüm al-Hadìs al-Nabawì, ditaḥīiq oleh Kamāl Yūsuf al-Hūt, Beirut: Dār al-Kutub al-'Ilmīyah, cet-I, 1410 H/1990 M.

Ibn al-Ṣalāḥ, Abū 'Amr 'Us̉mān bin 'Abdur Raḥmān bin 'Us̉mān bin Mūsā al-Kurdī alSyahrazūrī al-Syarkhānī, Muqaddimah Ibn al-Salāh fì 'Ulüm al-Hadïs, dita'liq dan ditakhrij oleh Abū 'Abdur Raḥmān Șalāḥ bin Muḥammad bin 'Uwaiḍah, edisi terbitan baru, Beirut: Dār al-Kutub al-'Ilmīyah, cet-II, 2006 M.

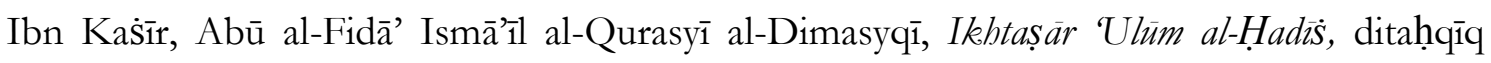
oleh Māhir Yāsīn al-Faḥl, Riyāḍ: Dār al-Mīmān li al-Nasyr wa al-Tauzī’, cet-I, 1434 $\mathrm{H} / 2013 \mathrm{M}$.

Idlibī-al, Șalāḥuddīn bin Aḥmad, Manhaj Naqd al-Matn 'inda 'Ulamä' al-Hadïs al-Nabawì, Beirut: Dār al-Āfāq al-Jadīdah, cet-I, 1403 H/1983 M.

Juyūsȳi, Muḥammad Ibrāhīm, Dirāsāt Haula al-Sunnah, Dār al-Ittiḥāt al-'Arabī, cet-I, 1396 $\mathrm{H} / 1976 \mathrm{M}$

Khațīb, Muḥammad 'Ajjāj, Ușül al-Hadìs: Ulümubu wa Muṣtalahubu, Beirut: Dār al-Fikr, cetII, $1391 \mathrm{H} / 1971 \mathrm{M}$. 
Hadith Book of Middle Age : The Study of Al-Targīb Wa Al-Tarhīb .... (Muhammad Anshori)

Khon, Abdul Majid, Pemikiran Modern dalam Sunnah: Pendekatan Ilmu Hadis, Jakarta: Kencana, cet-I, 2011.

Munżirī, Abū Muḥammad Zakīyuddīn Abū Muḥammad 'Abdul 'Az̄īm bin 'Abdul Qawī bin Salāmah bin Sa'ad, al-Targīb wa al-Tarbìb, Beirut: Dār al-Fikr li al-Ṭibā'ah wa al-Nasyr, cet-II, 1393 H/1973 M. Beirut: Dār al-Fikr li al-Ṭibā’ah wa al-Nasyr, cet-I, 1414 H/1993 M, Kairo: Dār al-Ḥadīis, 2007 M), Beirut: Dār al-Kutub al-'Ilmīyah, cet-II, $1426 \mathrm{H} / 2005 \mathrm{M}$.

Kifāyah al-Ta'abbud wa Tuhfah al-Tazabhud, ditaḥīi oleh Yusrī 'Abdul Ganī, Beirut: Dār al-Kutub al-'Ilmīyah, 1407 H/1987 M.

Nasution, Harun, Pembaharuan dalam Islam: Sejarah, Pemikiran dan Gerakan, Jakarta: PT Bulan Bintang, 1982.

Islam ditinjau Dari Berbagai Aspeknya, Jakarta: UI-Press, cet-V, 1985,

Islam Rasional: Gagasan dan Pemikiran, Bandung: Penerbit Mizan, cet-IV, 1416 $\mathrm{H} / 1996 \mathrm{M}$.

Qāsimī-al, Muḥammad Jamāluddīn, Qawāid al-Taḥdìs fì Funūn Muṣțalặ al-Hadìs, Beirut: Dār al-Kutub al-'Ilmīyah, t.th.

Saifuddin, Arus Tradisi Tadwin Hadis dan Historiografi Islam: Kajian Lintas Aliran, Yogyakarta: Pustaka Pelajar, cet-I, 2010.

Shalabi-Ash, Ali Muhammad, Bangkit dan Runtubnya Daulab Bani Saljuk: Kontribusinya bagi Peradaban Islam di Abad Pertengahan, trj. Masturi Irham dan Malik Supar, Jakarta: Pustaka Al-Kautasr, cet-I, 2014.

Sakhāwī, Abū 'Abdillāh Muḥammad bin 'Abdur Raḥmān, Fath al-Mugìs bi Syarh Alfìyah alHadìs li al-'Träqì, Kairo: Maktabah al-Sunnah, 1424 H/2003 M.

Șāliḥ, Șubḥī, 'Ulūm al-Hadìs wa Muștalahubu, Beirut: Dār al-'Ilmi li al-Malāyīn, cet-V, 1388 $\mathrm{H} / 1969 \mathrm{M}$.

Salīm, 'Amr 'Abdul Mun'im, Taisìr Dirāsah al-Asānìd li al-Mubtadi'ìn, Ma'a Amsilah 'Amalīyah Tu’ìn al-Ṭălib 'alā Taḥqùq al-Asānìd, Ṭantạa: Dār al-Ḍiyā', cet-I, 2000 M.

Sam'ānī, Abū Sa'ad 'Abdul Karīm bin Muḥammad bin Manșūr al-Tamīmī, al-Ansāb, ditaḥqīq dan dita'līq oleh 'Abdur Raḥmān bin Yạ̣yā al-Mu'allimī al-Yamānī, j-III, Kairo: Maktabah Ibn Taimīyah, cet-III, 1400 H/1980 M.

Suyūṭị, Abū Faḍl Jalāluddīn 'Abdur Raḥmān bin Abū Bakar, Tadrīb al-Rāñì fì Syarh Taqrīb alNawāmì, dengan pentaḥqị Abū Qutaibah Naẓar Muḥammad al-Fāryābī, Riyāḍ: Dār Ṭībah, cet-VII, 1425 H. 
Millatī, Journal of Islamic Studies and Humanities, Vol. 4, No. 1, Juni 2019: 14-34

Yatim, Badri Sejarah Peradaban Islam, Jakarta: PT Raja Grafindo Persada, cet-VII, 1998. 